\title{
Cancer as a disease of civilization in the sociological concepts of suffering, emotion and affect
}

\author{
Leon Szot - Kamil Kardis - Gabriel Pala - Ulbossyn Aimbetova
}

DOI: 10.18355/XL.2021.14.03.09

\begin{abstract}
The authors undertake a thorough analysis of the sociological concepts of suffering, emotion, and affect in the context of cancer as a disease of civilization. To that end, firstly, they explore the social logic of care and the gift in order to embark on the n. of the social relation between a designation of cancer as a disease of civilization and the development of modern societies. The authors examine the place and perception of cancer-affected persons and groups in societies of today. Subsequently, they analyze the sociological concepts of suffering, emotion, and affect while exploring a wide range of n.s related, among others, to the sociology of health, including in reference to particular situations of persons affected by cancer. In addition, the authors examine the significance of informal caregivers and the popularity of end-life care institutions for cancer patients. The authors also analyze emotions felt by cancer-affected persons as well as the role of groups and internet forums which gather cancer-affected persons, their closest friends and families.
\end{abstract}

Key words: sociology of suffering, sociology of emotion and affect, cancer as a disease of civilization, cancer support groups, cancer patients, cancer patients carers

\section{Introduction: The logic of the gift and care versus cancer as a disease of civilization}

It is widely acknowledged that the sociological concept of gift has been fundamental to describe private and public relations between human beings as it has been shown in social sciences since interdisciplinary and revolutionary works of Mauss on the subject of social giving, which de facto highlighted strengths and weaknesses of disciplines such as economics and philosophy (Kardis et al., 2019: 114). Mauss identified the gift as a process of exchange, a "Durkheimian total phenomenon" in which responsibility and obligation in societies are addressed through rituals and practices of receiving, giving, and offering. This theory has been broadened and used to describe diverse contexts, including micro-, meso-, and macrosocial phenomena, as well as epistemological n.s on human exchange in general (Tzanelli, 2007: vii). Of particular interest for the sociological reflection concerning cancer as a disease of civilization is a unique relation between the gift theory and care/affect theories at a micro-level encompassing a material or affective type of labor which is underscored by non-contractual values such as responsibility and trust. Both values play an essential role in relation to the sociological concept of suffering, for they generate and cement open and solid relations and interactions between an individual or a group that is affected by suffering in the form of distress, pain, or discomfort with other individuals or groups which do not suffer from any larger forms of pain or discomfort.

\section{Importance of multi-disciplinary research versus approaches to the necessity of cancer care in various modern socio-cultural contexts}

It was assessed in 2006 that over 6 million people died each year from cancer worldwide (Colditz, 2007: vii). In 2013, the number of deaths caused by cancer increased to as much as 8,2 million, whereas it is assumed that the number of cancer deaths will radically grow on an annual basis to reach 30 million in 2030 (Union For

XLinguae, Volume 14 Issue 3, June 2021, ISSN 1337-8384, eISSN 2453-711X 
International Cancer Control, 2013: 1). With the advancement of industrialization invigorated by a growing role of consumption processes among Western societies, the number of cancer-affected persons has gradually grown as of the 1920s. At present, cancer is so widespread that it has become classified as a disease of civilization ${ }^{1}$ - one of the distinctive labels by which our Western civilization is now known. As a Western civilization type of industrialization and consumption has spread all around the world due to globalization ${ }^{2}$ and mediatization ${ }^{3}$ processes, cancer as a disease has become recognized in all Eastern civilizations, including Chinese, Japanese, Indian, South American and most recently in isolated areas of the Earth inhabited by diverse tribes to whom this disease had been before unknown or had been very rare. Cancer has been the subject of an extended research effort since the introduction of radiotherapy in the 1920s and chemotherapy after the Second World War after the proliferation of X-ray and scanning machines. Regardless of the massive amount of research and the advancement of medicine, it is still known little about how to cure and combat different types of cancer (Groves, 2017: http://www.secondopinions.co.uk/cancer.html\#).

Cancer, by medical definition, is "a disease where body cells grow and divide uncontrollably. They can spread into nearby tn.s and may spread to other parts of the body through the bloodstream or lymphatic system. Cancerous tumours are called malignant." (Cancer Research UK, 2016: http://www.cancerresearchuk.org/aboutcancer/utilities/glossary/?letter=C) According to medical terminology, there are various types of cancer out of which some are defined as benign and some as malignant. Some types of cancers which are managed to be early diagnosed and treated might be cured (American Cancer Society, 2016: https://www.cancer.org/cancer/cancer-basics/what-is-cancer.html). Although cancer, as a disease, has become a multi-disciplined research subject, no other definition of cancer exists which would include socio-psychological or socio-anthropological elements indicating specificities of a cancer-affected person's patterns of social behavior, defining his or her approach to social interactions or his or her social position within societal structures. However, it is to a certain extent acknowledged that cancer-affected person's spiritual and psychological handling and bearing of the disease may vary, depending on accessible possibilities of particular cancer types' cures and treatment, individual abilities and character's traits of that person as well as the level of spiritual, social and psychological support of persons in similar situations and the closest environment of that person.

\footnotetext{
${ }^{1}$ In sociological terms, civilization is understood in this article as a spatio-temporal continuum and long-term dynamic structure as it was postulated by Kroeber, as the product of human evolution and its new phase, possessing a particular system of values embodied in a religion or beliefs with behavioural patterns and social norms which reflect a common set of beliefs or religious values. (Kroeber, 1973: 5-26. Kardis, 2019: 155). As Wei connected various elements of today's polemics concerning the meaning of civilization - civilization is also to denote a large population and has a geographic scope which has distinctive socio-cultural characteristics; a sophisticated writing system; arts, music, literature; developed sciences and technologies; a coherent legal system; and social, political and military organizations. (Wei, 2011: 1-9).

${ }^{2}$ Taking into account that cancer is classified as a disease of civilization, the term globalization is understood in this article as inter-civilizational diffusion which is ongoing due to development of technologies, mass communication and world economics which include daily social interactions and relations. (Vertigans - Sutton, 2002: 31-46).

${ }^{3}$ Mediatization -"the theory which argues that it is the media which shape and frame the processes and discourse of political communication as well as the society in which that communication takes place". (Lilleker, 2006: 32-38). Mediatization is the process that may influence and change the society in all spheres of life." Krotz, 2009: 21-23).
} 
Cancer is not a new disease and has been known in most societies for centuries. It had been recorded in manuscripts as early as $3000 \mathrm{BC}$ in ancient Egypt. At that time, the disease was classified as non-curable. The ancient Greeks and Romans referred to that disease in 280-50 BC and compared it to a shape of a crab. The term was later translated as cancer. Only in the $18^{\text {th }}$ century, the Scottish surgeon suggested that some types of cancer might have been curable and certain tumors could have been removed. The $19^{\text {th }}$ century saw the birth of scientific oncology with a modern microscope which commenced to be used to analyze the cancer cells more closely. From ancient times, physicians had difficulties in identifying causes of cancer. The ancient Egyptians considered the unfavourability of gods as a main cause of cancer. Hippocrates, in contrast, attempted to explore causes of cancer from a perspective of, how he called it, four body fluids that constituted a human body. Finally, in 1838, German pathologist Johannes Muller proved that cancer was made up of cells, not lymph as it was earlier believed and that cancer cells did not stem from normal and healthy cells. Muller introduced the term blastoma, i.e., budding elements developed between normal tn.s, while his student, Rudolph Virchow, proved that all cells, including cancer cells, came from other cells. Subsequently, between the 1800s and 1920s, trauma was considered the predominant reason to cause cancer. Later on, in 1649, two Dutch doctors introduced a new theory that stated that cancer was an infectious disease and cancer patients were meant to be isolated. Modern knowledge about cancer is dated as of 1915, when Koichi Ichikawa and Katsusaburo Yamagiwa at Tokyo University applied coal tar to rabbit skin, by the same token inducing them cancer cells. Since that time, the following, among others, carcinogenic substances have been recognized and recommended not to be used by humans: coal tars and their derivatives, some hydrocarbons, aniline, asbestos, ionizing radiation. It has also been recorded that some viruses could be linked with cancers, such as: long-standing infections with hepatitis $\mathrm{C}$ and $\mathrm{B}$, Epstein-Barr virus, herpes viruses, HIV, human papilloma viruses, and many others (American Cancer Society, 2016: https://www.cancer.org/cancer/cancer-basics/what-is-cancer.html). At the beginning of the $19^{\text {th }}$ century, one death in 50 occurred due to cancer, however already in the first years of the $20^{\text {th }}$ century, 27 deaths out of 50 were caused by cancer worldwide (Groves, 2017: http://www.second-opinions.co.uk/cancer.html\#).

Until recently, research about cancer has been neglecting the $\mathrm{n}$. of how an individual could spiritually, socially, and psychologically handle his or her disease so that it could potentially have a positive alleviating effect on a particular type of his or her cancer. For a person who has just found out that he or she is affected by cancer, the word 'cancer' is a dreadful word. Until postmodern times, cancer was considered a taboo, even in Western societies. Apparently, if a member of a family was affected by cancer, this matter was kept within the family cancer was considered an obscure disease that was socially unacceptable. Certain absurdities and superstitions occurred during that time. For instance, if a healthy person met a cancer-affected person or had heard that a person had cancer; it was believed that that healthy person could get cancer too. At present, cancer-affected persons receive mostly words of compassion from their family, friends, and acquaintances (Groves, 2017: http://www.secondopinions.co.uk/cancer.html\#).

Persons who are affected by cancer and their closest social environment usually tend to intensify their knowledge about cancer through an extensive reading about it, seeking novelties that are aimed at treating cancer, participating in forums for canceraffected persons to understand what kind of adversary there are fighting with. Moreover, they endeavor to identify the best ways to alleviate the persons' suffering associated with cancer while trying to resort to accessible health care offered by the state, private clinics, and rarer - by alternative medicines' remedies. Nonetheless,

XLinguae, Volume 14 Issue 3, June 2021, ISSN 1337-8384, eISSN 2453-711X 
some cancer-affected persons regard their disease as a death sentence and prefer to keep this information for themselves due to fears of long medical treatment such as chemotherapy or radiotherapy. For most cancer-affected persons, cancer is a dramatic life-changing experience for it reshuffles life priorities and radically changes the social position of the affected person. The person ceases to be a dynamic society member participating in civilizational daily routine efforts of particular social groups embedded with certain clearly defined responsibilities and becomes, in his or her opinion and of his or her environment, a person aside from this routine stepping on the margins of the society and being a burden for his closest environment. In these cases, an effective, easily accessible state cancer care plays a fundamental role in the care provision to treat cancer and ensure social importance of the cancer-affected persons' position in society.

Today, cancer-related researches are not limited to medicine only. Medical anthropology, social psychology, sociology of health, and, most lately - sociology of emotion and affect have taken a challenge of identifying n.s that could be of help to medical efforts to form a complex approach towards understanding cancer and how to alleviate physical and spiritual pain caused by that disease. In addition, the world of politics in many Western countries have attempted to introduce measures that have been meant to facilitate access to adequate oncological health care which has also engaged social workers instructing families and the closest ones of cancer-affected persons how to support them spiritually and mentally in their painful experience. The 2015 study by Soneji and Yang on the subject showed that the United States spent on cancer-related care far more than any European country. According to the study, the United States spent 435 billion USD, 325 USD, 434 billion USD more than European countries' health care for breast, colorectal, and prostate cancer, respectively. Regardless, mortality rates associated with the mentioned types of cancer in the United States were, surprisingly, significantly higher compared to those in Europe (Horgan, 2015: 15-17).

In 2013, at a European Cancer Congress, scientists presented their findings, simultaneously published in the Annals of Oncology which demonstrated that an important difference in health and wealth expenditure indicators was detected between Eastern and Western European countries, where indicators were higher in Western European countries. It appeared that higher health and wealth expenditures were concomitant with decreased cancer mortality and increased cancer incidence. For instance, in the case of breast cancer, this concomitance was more visible. The scientists recorded that the more was spent on health in a country, the fewer deaths occurred after a cancer diagnosis. In addition, they noticed that despite many initiatives of standardization of public health policies in European Union member states, health expenditures continued to be higher in Western European countries with a higher number of positive effects related to cancer treatments (Ades et al., 2013: 2897-2902). It was acknowledged in the study that cancer was a leading cause of mortality in Europe and that there was a marked deficit between resources required to control it and those spent on this n.. The study can also be treated as a warning sign over inequalities in cancer care in the European Union countries.

Regardless of these inequalities, it is certain that, generally, cancer patients belonging to the Western civilizational hemisphere demonstrate a traditionally stronger will of commencing cancer treatment to stand against the odds brought by the cancer disease compared to cancer-affected persons in Middle Eastern countries and elsewhere. In most Middle Eastern countries, cancer care, including palliative care, is often misunderstood among cancer patients themselves, health professionals, and the public at large. Apparently, it is still difficult to explain the necessity to combat cancer, particularly in its terminal stages due to restrictive culture and socio-religious traditions, which, among others, do not allow applying an extended medical and 
psychological treatment for women or give up on those who do not want to accept any care due to being religiously persuaded that terminal diseases in general equals death. Moreover, Islamic societies, unlike Western and Eastern European ones, are considered more death accepting and seem to live in coexistence with awareness of the inevitability of death. Such an approach has a striking impact on how cancer patients and their families view death while possessing a strong religious conviction of what lies beyond death (Silbermann et al., 2012: 15-28). In turn, the Indian society's religious traditions of accepting death and other factors such as a lack of cancer care awareness (Mushini, 2016: 235-242), poor access to cancer care centers, and late cancer detections strongly influence a general societal approach towards necessities of cancer treatment (Earnst \& Young LLP, 2015: 2-5). Per-comparison, the Chinese societal and medical traditions deal with it differently. A prevalent deathaccepting approach has not been an obstacle but has become a vehicle to apply a specific multimodal approach towards cancer treatment, which today has made China one of the leading countries in targeted cancer therapies (Ma - Lin - Zhen, 2008: 2-9).

\section{Sociological concept of suffering versus cancer as a disease of civilization}

Regardless of any type of disease, suffering is the most often and observable word to be uttered by those who feel discomfort, pain, and lack of harmony. It is nearly impossible to distinguish various types of suffering to identify its intensity unless other words are used to describe suffering, such as pain, discomfort, injury, or damage. In the most common meaning of suffering, it is defined as "physical or mental pain that a person or animal are feeling" (The Cambridge Advanced Learners' Dictionary, 2010). At any historical time humanity spoke its voice, suffering was always mentioned. Since the inception of humanity, suffering has been its experience; however, humanity could not impassively accept it as an inevitable and normal human condition. Suffering hurts due to the pain it involves and its overwhelming dominance over our senses. The phenomenon of suffering is most fundamentally opposed to us, and at the same time, it discloses the truth about the actual purpose of our lives (Wilkinson, 2005: 1-2).

\subsection{The Problem of Suffering as a concept versus the lived experience of pain}

Weil accentuated that "suffering is an uprooting of life, a more or less attenuated equivalent of death" and that its effect reduced a human experiencing pain to nothing (Weil, 1966: 77). Weber identified suffering as "the driving force of all religious evolution" through which humans venture to deduce the meaning of the world. As Wilkinson noticed, a similar approach was taken by Parsons and Tenbruck. In turn, Marx recognized "the sensuous knowledge of suffering" as a vital force standing behind any social change. He placed the suffering in the context of religion that he considered an "illusionary sun" that became a protest against suffering, which was brought about by the proletariat's immiseration (Marx - Engels, 1950: 134). Durkheim was convinced that the so-called social psychology of human suffering considerably advanced the progress of human civilization (Durkheim, 1964: 233-255). Wilkinson pertinently stressed that "the lived experience of suffering appears to be a direct focus of sociology" (Wilkinson, 2005: 2). He continued by arguing that the problem of suffering was almost always implicit in sociological research. One could go as so far as to conclude that sociology, in all cases, deals with consequences and causes of human suffering such as injustice, moral anxiety, and cultural poverty. Nevertheless, he rightfully noticed that in recent years, sociological commentators and sociologists had failed to give adequate consideration to the actual impact of suffering experienced by people. Similar views on this $\mathrm{n}$. were presented by other contemporary

XLinguae, Volume 14 Issue 3, June 2021, ISSN 1337-8384, eISSN 2453-711X 
sociologists such as Kleinman (1995: 8-24), Das (Das, 1997:563-557), Bourdieu (1999: 607-627), and Frank (2005: 30-45).

Given that with the advancement of the mass media globalization effects, more information on disasters, damages, and suffering worldwide, in general, has been available to us, it is broadly recognized that the knowledge regarding the experience of suffering still remains seriously deficient. This realization in the sociology of suffering is called a "new awakening," It is projected to help inquire into existential components of the suffering phenomenon and serve as an impetus for a lively sociological debate (Wilkinson, 2005: 3). Some question why sociology should ponder scientifically on the suffering experience while other disciplines such as philosophy, theology are better equipped for this n.. There is a simple answer to address this $\mathrm{n}$.. The evolution of sociology, its scientific instruments describing the quality and quantity of many phenomena actually allow sociology to conduct effective research on the suffering problem. An interdisciplinary approach, as suggested for instance by Graubard, might also be applied in sociological research of that matter (Graubard, 1996: v-x).

Although few authors took up the subject of social suffering in the $18^{\text {th }}$ and $19^{\text {th }}$ centuries, the concept of social suffering has become vital for sociologists and anthropologists only as of the 1990s (Wilkinson, 2016). There are three groups of researchers that have taken the challenge of describing and analyzing the experience of social suffering. In medical anthropology, social suffering accounts for the sociocultural elements of the pain experience. The researchers such as Frank and Illich criticized biomedicine for downsizing the socio-cultural components of pain care, while Kotarba, Kleinman, Morris, Horn, Munafo pointed at a lack of interaction between social contexts, cultural meaning, and neurophysiological processes. The second group - ethnographers and sociologists: Bourdieu, Skultans, Sheper - Hughes (Wilkinson, 2005: 6), and Renault (2008: 35-42) understood portraying what suffering did to individuals as a vital part of the political process which treated the suffering experienced as adversity that should be part of public concern. The third group of researchers, including Ignatieff, Kleinman, Boltanski, Moeller, Shaw, Tester (Wilkinson, 2005: 6), Chouliaraki (2006: 1-18), were convinced that media failed short of providing a real substance of human suffering, and suffering in general and that the public tends to ignore the responsibility to support those who suffered and those in need. Finally, the fourth group of researchers might be added to the debate, who significantly influenced what we know today about the experience of suffering Marx, Weber, Durkheim as well as Arendt, of whom the latter studied social suffering as being considered under the influence of feminism and analyzing distressing states of bodily feeling (Wilkinson, 2005: 6).

In recent years, the concept of social suffering in sociological literature usually has denoted not only the lived experience of pain but also damage, deprivation, loss, and injury. This has implied that human afflictions might be encountered in manifold forms and their effects are multiple depending on particular social conditions and noticeable forms of culture. At present, sociologists and cultural anthropologists research how certain subjective elements of distress are rooted in social situations and by which cultural factors they are conditioned, and to what extent. Moreover, the researchers assume that the social reality "is inscribed upon the embodied experience of pain" and that most often, an individual's suffering is seen as "a manifestation of social structural oppression and/or collective experience of cultural trauma" (Wilkinson, 2005: 6).

The sociology of health, medical anthropology, and social medicine consider social suffering as being associated with attempts to enlarge the biomedical conceptualization of pain in order to identify ways which are curtailed by sociocultural conditions and in which responsiveness to pain experience as well as to the 
treatment can be recognized (Good et al., 2005: 7). Researchers of the three disciplines refer to health care practices and point out that they should be better attuned to the embodied experience of pain, including chronic pain. In contrast, the practices should take into account individual social conditions and the fact that the person's condition of health is an accumulative product of diverse social processes and events (Wilkinson, 2005).

In French and American sociological contexts, the works and research regarding the experience of suffering cover n.s that clearly relate to social sciences and political science, and civic ethics. Today, this trend has become a common practice to be used by sociologists in other countries such as the United Kingdom and other European countries (Wilkinson, 2005). This approach is also partially used in works concerning the sociology of suffering and, largely, by the sociology of emotion and affect, which, among others, directly deals with emotions and effects associated with illnesses and diseases.

\subsection{The emotion and affect as sociological concepts versus the individual state of illness and disease}

The sociology of emotion and affect is a new area of sociological research that has been based on the works of Hochschild (Hochschild, 1979: 551-575), Scheff (1983: 333-354), Kemper (1980: 1418-1423), Collins (1981: 984-1014), Barbalet (1998), James (1918: 442-486), Simmel (1950: 409-424), Heise (1979) and Mead (1967) who explored the importance of emotions in light of social interactions as well as the philosophical writings of Aristotle (2009: 5-37), Kant (2013: 131-150) and Sartre. This new field has been recognized very recently as a subfield of sociology. However, its first essential works started to be published as of the late 1970s. Its researchers have recognized that emotions and affects are the driving force of social policies. They are the object of policies that aim to reduce anger-related violence, loneliness, depression and improve well-being.

The main assumptions of emotion and affect sociology have lately been used by other sociological sub-disciplines such as economic and cultural sociology, social psychology, sociological theory, and political sociology. The field is particularly dynamic among researchers in the United States and Australia (Thoits, 1989: 317 320). The emotion and affect concepts aim at understanding of the role of emotion as it relates to the policy and social research; encouraging new critical theories on social emotions and affect; revealing the common affective and emotional elements of diverse sociological sub-disciplines; exploring the roles of emotions as a primary sociological force and concept; and employing current and new sociological methodologies of measurement of emotions and affects (Piterie, 2017: https://www.tasa.org.au/thematic-groups/groups/sociology-of-emotions-and-affect/).

In the sociology of emotion and affect, emotions might be distinguished from moods, sentiments, feelings, and affects. Feelings and affects are considered as less specific terms compared to moods and sentiments. The term feeling includes experiences of physical drive states such as hunger, fatigue or pain, and all emotional states. Emotional states, which are illustrated by facial and bodily expressions, include, among others, sadness, happiness, disgust, anger, fear, surprise, and contempt (Ekman - Friesen, 1986: 159-168). Meanwhile, affects correspond to negative and positive evaluations, e.g., disliking or liking of an object, behavior, or idea. Affects are believed to have activity and intensity dimensions.

Most importantly, emotions are regarded as having culturally delineated forms of affects or feelings, while moods are chronic, less intense, and are believed to be hardly associated with an eliciting situation. In turn, sentiments are defined as "socially constructed patterns of sensations, expressive gestures, and cultural

XLinguae, Volume 14 Issue 3, June 2021, ISSN 1337-8384, eISSN 2453-711X 
meanings organized around a relationship with a social object - usually another person...or group such as a family or friends." Sentiments might be portrayed through friendship, loyalty, parental love, acute responsiveness to social losses in the form of sorrow or envy (Gordon, 1981: 262-292). This interpretation affirms social antecedents as well as social acquisition and shaping of emotions, which make it possible for sociology to explore and analyze emotions per se (Thoits, 1989: 319-320). Most sociologists of emotion and affect assume that emotions are not simply biophysiological phenomena but are also a product of social influences. Symbolic interactionists (e.g., Hochschild) and social construction theorists (e.g., Gordon) have regarded emotions as dependent on definitions of emotion vocabularies, beliefs, and particular situations, which might vary across location and time. The so-called "positivists," e.g., Kemper or Mazur, have perceived emotions as automatic, invariant and patterned responses to particular social stimuli (Thoits, 1989: 319-320). Regardless of the current sociological debate among researchers, the sociology of emotion and affect effectively commenced to describe emotions and affects related to an individual's state of illness and/or disease, which are a product of particular social stimuli as well as of a painful state of illness or disease-affected persons. The aim of this type of research has been to contribute to a general understanding of emotions of the ill or deceased persons; enrich interdisciplinary knowledge on the topic of emotions as well as to help illness or disease affected persons, groups of illness or disease affected persons, their families, and friends; as well as practitioners, i.e., medical and social workers in their daily work in the hospices, hospitals and during home visits.

\subsection{The sociological concepts of suffering, emotions and affect versus cancer as a disease of civilization}

The sociological concept of suffering and the concept of emotion and affect both seem to have a common departure point in the case of cancer disease and other lifethreatening diseases. The pain, which is understood as a form of suffering, is inscribed on emotions, sentiments, moods, and cancer-affected persons' affects. As a palpable feeling, pain manages, influences, and overwhelms all social stimuli of canceraffected persons. It must be emphasized that cancer diagnoses have the power to transform a person in a sense that putting a "cancer' name on the disease makes it a terrifying experience to hear it even if there is yet no change in the condition of a cancer-affected individual (Blaxter, 2004: 29-32).

It is acknowledged that if a person is affected by cancer with a high probability of survival, then his or her phenomenological experience is conditioned by the disease and its impact rather than by factors such as occupations, accomplishments, and relationships, which is more visible in the cases of cancer patients with a low probability of survival. As the sociology of emotions is a relatively new science, there are few accessible writings concerning emotions associated with illnesses and diseases, including cancer diseases. Moreover, the number of analyses that would cover the $n$. of cancer disease from joint perspectives of sociology of suffering and sociology of emotions and affect is concomitantly small.

3.3.1 Selected examples of studies related to "the emotion work" using approaches of sociology of emotions and affect, and the sociology of suffering - cancer patients, their social environment, and cancer support groups

In her analysis regarding the sociology of emotions in contested illness environmental case, Jacobson discussed how gender and the sense of community could produce a conflict of emotions related to cases of cancer diseases that occurred inside the community. She accentuated that contested illness research often described individuals' emotional states without referring to larger social factors such as gender, 
sense of community, and assumptions related to a dichotomy of emotion-logic. She investigated the case of the Acreage in Florida (the United States), where a cancer cluster was established; however, an environmental cause was not identified. The researcher used data gathered from in-depth interviews conducted among 57 residents of the town. She concluded that disparate feeling rules linked with one's sense of community, gendered notions of logic and emotion, as well as projections and perceptions of - what would neighbors feel or think - largely contributed to a serious "community dissension." She found out that emotions of fear, grief, and anger were repetitively expressed inside the community, while the feeling of pain was considered as a more private and individual experience that was not often mentioned (Jacobson, 2016: 238-253).

Other researchers of sociology of emotions and affect (Yoo et al., 2010) focused on an unreservedly different aspect of approach towards the cancer disease. The researchers used as a guideline the Hochschild's thesis, which stipulates that the emotion work should elicit feeling in others and try "to maintain" one's own social roles and memberships by adhering to "feeling" norms and expectations. The researchers explored the $\mathrm{n}$. of the sociological relationship between emotions and breast cancer survivors while analyzing the self-disclosure of breast cancer diagnosis in an ethnically and racially diverse environment. They conducted extensive in-depth qualitative interviews among 176 women - residents of California (the United States): African American, Caucasian, Asian American, and Latina who were diagnosed with breast cancer stages 0 , I or II in the last 4 years. Interviewees also expressed their views about the quality of accessible social support. Respondents extensively spoke about "the various elements of emotion work in the cancer disclosure process including: managing others' worry, protecting and soothing others, and educating and instructing others." They often conveyed that they felt hopeless, feared death, and suffered from depression. For interviewees, self-disclosure "without calculating emotional management" signified that they were ready to receive support and could demonstrate an increase in emotional resources. The researchers concluded that women with breast cancer needed "an honest disclosure and less emotional management of other feelings." They underlined that there was a need to conduct educating campaigns about cancer experiences and the consequences of cancer treatment in society, particularly among ethnic and racial minorities. The research showed that the fears of burdening family and friends were the main concern of interviewed breast cancer patients and that the degree of stigma concerning breast cancer varied across ethnic and educational backgrounds as well as age and social status. Young women were identified as having "more stigma" than older women, while recently arrived Chinese and Latina immigrants viewed cancer as terminal, contagious, or caused by immoral behavior (Yoo et al., 2010: 205-215).

Charmaz, in her study, took a view focused on the feeling of suffering as perceived and felt by the chronically ill, including cancer patients (Charmaz, 1983: 168-195). She drew her conclusions based on data taken from qualitative research among 57 chronically ill from Northern California with the age range from 20 to 86 years, out of which $50 \%$ constituted persons of the middle-class occupations. The researcher stressed that the language of suffering used by her respondents corresponded to the language of loss. Chronically ill persons underlined "the loss of self" for they resorted to healthy images of themselves which were going away without being replaced by the new valued ones. Her respondents spoke of the following contextual feelings: being discredited by the society, being isolated from the society, being afflicted with an unbearable intensity of pain, longing for hope, being continuously fatigued; and enumerated the following emotions: grief, anger, apathy, resentment of one-self and the surrounding environment, sadness, hopelessness. In conclusion, the researchers

XLinguae, Volume 14 Issue 3, June 2021, ISSN 1337-8384, eISSN 2453-711X 
criticized medicine for a restricted definition of suffering, which targeted the physical discomfort only without a broad reflection of "the loss of self."

In another analysis, in Poland's biggest sociological qualitative study about the situation of cancer patients, some elements of the approach of sociology of emotions and affect were also applied. The study was prepared for an insurance company and conducted among 125 cancer patients in 15 different cancer care centers. The researchers organized focused session groups to perform in depth-interviews. Each session included 7-12 persons. The patients were up to 3 years after the completion of cancer treatment. The study was divided into several sections which concentrated on: the complex situation of cancer patients before diagnosis and during cancer treatment; relations between doctor and the cancer patients; genetics - accessible treatments for cancer; evaluation of cancer treatment costs, relations between the cancer disease and participation of cancer affected persons in professional life; acquirement of awareness on the cancer disease; the role of family and friends in the course of development of the cancer disease of their loved ones; support of acquaintances to cancer-affected persons; sexual life and the cancer disease; the cancer disease and a new life; as well as recommendations and prognosis. The respondents confirmed that medical doctors downsized the patient's emotional sphere and that their contact with a cancer-affected person was reduced to a minimum. Nearly all respondents complained about medical doctors' lack of empathy while informing about cancer diagnosis (Profile Poznań for AXA Life and Social Foundation, 2014: 16-18). The bulk of negative emotions among respondents mirrored difficulties that occurred during their types of cancer treatments, such as deficiencies of the cancer care system and unfavorable labor system to most respondents - many lost their employment or were forced to work part-time. During the interviews, respondents referred to the emotions of fear, hopelessness, disappointment, resentment, shame, and humiliation due to having the cancer disease, as well as to the feelings of fatigue, pain, being socially discredited, demeaned, and degraded (Profile Poznań for AXA Life and Social Foundation, 2014: 18-21). It must be emphasized that the method used to conduct the research for the study - focused session groups turned eventually into a cancer support group where cancer and former cancer patients could share their emotional states (Profile Poznań for AXA Life and Social Foundation, 2014: 22-23; 29-30).

The popularity of private cancer support groups functioning outside the cancer care system, either as internet forums or as groups meeting in person on a regular basis, has been increasing. This subject has also become a new interesting theme for the sociology of emotion and affect as well as for the sociology of suffering. To that effect, the research work has so far been conducted mainly through the means of interviews with focused session groups. For instance, Perry and Glover crafted a socalled performance text to demonstrate "the emotion work" of how cancer patients "craft liveable truths" after cancer diagnosis. The researchers interviewed 26 members of one of Gilda Clubs. ${ }^{4}$ A composite character named Henry weaved all members' lived experiences of diverse emotional states such as happiness, fear, anxiety, sadness, friendship, optimism, and institutional processes that shaped them during individual cancer diagnosis and its treatment. It turned out that the study started to resemble a book on emotional states of cancer patients rather than a scientific paper and served

\footnotetext{
${ }^{4}$ The Gilda Club - a meeting place for cancer-affected persons, their families and friends, an initiative that offer support and networking groups for cancer-affected persons and their closest communities. The Club was named in tribute to Gilda Radner who died of ovarian cancer in 1989 and was founded by Joanna Bull who was Radner's psychotherapist. The Clubs are linked to the Cancer Community Support Organization and are actively working in Canada and the United States. See http://www.cancersupportcommunity.org/mission-vision-and-history.
} 
unintentionally as a healing process for interviewees who commenced to treat the research as one of their support groups' activities (Perry - Glover, 2011: 395-403).

Most researchers have acknowledged that there are not many sociological studies covering the $n$. of cancer support groups from joint perspectives of the sociology of suffering and sociology of emotion and affect. Despite positive reports regarding many Internet cancer support groups, few studies would help choose an appropriate cancer support forum or group that could be used to conduct valuable research. Therefore, Eo (et al.) have recently developed selection criteria - cancer group identifiables. To that effect, the researchers undertook an Internet-based study of cancer pain experience amidst cancer patients who were recruited through Internet cancer support groups. The main selection criteria included: mission and purpose of the group; private or public domain; target users of the group; scope of the group; contents of the group's website; dynamics within the group's website; as well as credibility and authenticity of the website's owner. The researchers recommended further work on the refinement of the criteria, for they were the only ones to conduct the research of this type (Im et al., 2010: 183-188).

\subsubsection{Selected examples of studies related to "the emotion work" using approaches of sociology of emotions and affect, and the sociology of suffering - the role of cancer caregivers and hospices}

Multiple studies showed that the best and adequately curtailed emotional support to cancer patients is given by their loved ones. For instance, Olson conducted a nine-year research on the aspect of cancer caregiving by spouses and the closest persons of cancer-affected individuals in which she focused on emotions, affects, and feelings associated with their interactions with cancer-affected loved ones, including the lived experience of feelings such as pain and emotions, e.g., sorrow, disappointment, confusion to count a few. ${ }^{5}$ The act of caregiving is herein a relationship which is based on previous relations with a then not-a-cancer-affected person. The researcher conducted interviews with 32 Australian cancer carers, during which her interlocutors admitted that the initial cancer diagnosis of their loved ones entirely changed the character of their relationship with them and vice versa. On many occasions, interlocutors confessed that there were times when they had to receive emotional support from their cancer-affected spouses rather than offering them full emotional support and that the persistent, repetitive thoughts-styled awareness about the hopelessness of the given situation reminded them about the $\mathrm{n}$. of their own mortality. The spouses and the closest persons of cancer patients disclosed that they seriously lacked an emotional shield that could help them manage the provision of care sensitively to their loved ones. Moreover, they often mentioned that the caregiving was detrimental to their physical and mental health, not mentioning their finances (Olson, 2015: 1-3). The researcher also analyzed caregiving work contexts in her country, including the health care system and financial aid for caregivers. She referred to a general spectrum outlined by Twigg and Atkin, who categorized carers according to major characteristics of health care systems and welfare policies in developed countries: carers as resources; carers as co-workers; carers as co-clients; and superseded carers (Olson, 2015: 31; Twigg - Atkin, 1994), and concluded that developed countries heavily relied on informal caregivers regardless considerable

\footnotetext{
${ }^{5}$ Spouses and friends of cancer patients who provide them informal emotional and physical support without pay are called informal caregivers or carers. See: (Blum - Sherman, 2010: 243258).
}

XLinguae, Volume 14 Issue 3, June 2021, ISSN 1337-8384, eISSN 2453-711X 
changes between health care policies in, e.g., the United States, the United Kingdom, New Zealand and Australia (Olson, 2015: 31).

Hospices and palliative/end-life care centers are an alternative for cancer patients who cannot have an informal cancer caregiver and/or their physical and/or mental debilities do not allow them to be cared for at home. Sampson (et al.) prepared a thematic analysis which was applied to 594 anonymous free text responses received from patients and carers. The aim of the analysis was to base on it a research study of patients' and carers' experiences of palliative care. The researchers concluded that the emotional experience of care was the most significant aspect that patients and carers wrote about and that "the care" was interpreted as having a sociological relationship that produced and shaped the emotional states of patients and carers. The care was also understood as a key domain of respect, renewal, finding refuge, and restoration, particularly as seen by cancer patients. The study showed that emotional experience of care embraced both psychosocial needs of care per se and drew on professional expertise, interpersonal skills, which some were by default taken too much for granted. An important aspect identified by researchers was a sense of autonomy and connectedness with an outside-hospice society that was given to patients in order to boost their optimism and positive emotions (Simpson, 2014: 291-298).

\section{Conclusion}

It is evident that the sociology of emotion and affect, along with the sociology of suffering, can be instrumental in complementing biomedical efforts by identifying ways to improve social relationships of cancer-affected persons and their social environment. At present, the sociology of emotions and affect as well as the sociology of suffering aim at exploring and describing qualitatively emotional states of canceraffected persons and emotional lived experiences as products of not only a physical state of cancer-affected persons but also an emotional manifestation of their changed social roles following a cancer diagnosis. As the "emotion work" is a new approach towards sociological measuring and describing of emotions, both the sociology of emotion and affect as well as the sociology of suffering have large maneuverability to take up the challenge to analyze sociological relationships of cancer patients and cancer carers.

\section{Bibliographic references}

ADES, F. - SENTERRE, C. - DE AZAMBUJA, E. - SULLIVAN R. - POPESCU, F. - PARENT, F. - PICCART, M. 2019. Discrepancies in cancer incidence and mortality and its relationship to health expenditure in the 27 European Union member states. In: Annals of Oncology, vol. 24, n. 11, pp. 2897-2902.

BARBALET, J. 1998. Emotion, Social Theory, and Social Structure: A Macrosociological Approach, Cambridge University Press, Cambridge.

BLAXTER, M. 2004. Health, Polity Press London.

BLUM, K. - SHERMAN, D. W. 2010. Understanding the Experience of Caregivers; a Focus on transitions. In: Seminars in Oncology Nursing, vol. 26, n. 4, pp. 243-258.

BOURDIEU, P. 1999. Weight of the World: Social Suffering in Contemporary Society. Polity Press, London.

THE CAMBRIDGE ADVANCED LEARNERS' DICTIONARY. 2010. Cambridge University Press, Cambridge.

CHARMAZ, K. 1983. Loss of Self: A Fundamental Form of Suffering in the Chronically Ill. In: Sociology of Health and Illness, vol. 5, no. 2, pp. 168-195.

CHEW, A. 2009. Aristotle's Functional Theory of the Emotions. In: Organon, vol. 9, no. 1 , pp. 5-37.

CHOULIARAKI, L. 2006. Spectatorship of Suffering, Sage Publications, London. COLDITZ, G. E. 2007. Encyclopedia of Cancer and Society, vol. I, Los Angeles. 
COLLINS, R. On the Microfoundations of Macrosociology. In: American Journal of Sociology, vol. 86, pp. 984-1014.

DAS, V. 1997. Sufferings, Theodicies, Disciplinary Practices, Appropriations. In: International Journal of Social Science, vol. 49, pp. 563-557.

DELVECCHIO GOOD, M. - BRODWIN, P. - GOOD, B.J. - KLEINMAN, A. 2005 (eds.): Pain as Human Experience: An anthropological perspective. University of California, Berkely.

DURKHEIM, E. 1964. The Division of Labour in Society. Free Press, New York London.

Earnst \& Young LLP. 2015. Call for Action: Expanding Cancer Care in India. Earnst \& Young LLP Publishing, Kolkata.

EKMAN, P. - FRIESEN, W. V. 1986. A New Pan-cultural Facial Expression of Emotion. In: Motivation \& Emotion, Vol. 10, pp. 159-168.

FRANK, A. W. 2005. The Renewal of Generosity: Illness, Medicine and How to Live. University Chicago Press, Chicago.

GORDON, S. L. 1981. The Sociology of Sentiments and Emotion. In: M. Rosenberg, R.H. Turner (eds.) Social Psychology: Sociological Perspectives. Basic Books, New York, pp. 562-292.

GRAUBARD, S. R. 1996. Preface to the N. Social Suffering. In: Deadalus, vol. 125, n. 1 , pp. v-X.

HOCHSCHILD, A. R. Emotion Work, Feeling Rules, and Social Structure. In: American Journal of Sociology, vol. 85, pp. 551-575.

HEISE, D. R. 1979. Understanding Events: Affect and the Construction of Social Action. Cambridge University Press, Cambridge.

HORGAN, J. 2015. Cancer Spending Higher in the U.S. than in Europe. In: Scientific American No. 6.

IME. O. - CHEE, W. - TSAI, H.M. - LIM, H. J. - GUEVARA, E. - LIU, Y. 2010. Evaluation Criteria for Internet Cancer Support Groups. In: Computers, Informatics, Nursing, vol. 28, n. 3, pp. 183-188.

JACOBSON, G. 2016. The Sociology of Emotions in Contested Environmental Case: How Gender and the Sense of Community Contribute to Conflict. In: Environmental Sociology, vol. 2, n. 3, pp. 238-253.

JAMES, W. 1918. The Principles of Psychology, vol. 2, Dover.

KARDIS, M. - STURAK, P. - KRALIK, R. - NGUYEN TRONG, D. KORZHUEV, A. V. - KRYUKOVA, N. I. 2019. A sociological-religious probe into contemporary global Salafi jihadism. In: European Journal of Science and Theology, vol. 15 , n. 4 , pp. 113-125.

KARDIS, M. - KARDIS, K. 2019. Religia a wartości na tle tożsamości kultury polskiej i litewskiej. Analiza socjologiczno - historyczna w oparciu o nauczanie kardynała Stefana Wyszyńskiego. In: Historia Ecclesiastica: časopis pre dejiny cirkví a náboženstiev v Strednej Európe, vol. 10, n. 1, pp. 149-175.

KEMPER, T. D. 1980. Sociology, Physiology and Emotions: Comment on Schott. In: American Journal of Sociology, vol. 85, pp. 1418-1423.

KLEINMAN, A. 1995. Writing at the Margin: Discourse between Anthropology and Medicine. California University Press, Berkely.

KROEBER, A. L. 1973. Style and Civilizations, Greenwood Publishing Group. Virginia.

KROTZ, F. 2009. Mediatization: Concept with Which to Grasp Media and Societal Change. In: K. Lundby (ed.): Mediatization, Concept, Changes, Consequences, Peter Lang Publishing. New York - Oxford.

LILLEKER, D. G. 2006. Key concepts of Political Communication. Sage Publications Ltd., London.

XLinguae, Volume 14 Issue 3, June 2021, ISSN 1337-8384, eISSN 2453-711X 
DE LOURDES BOURGES, M. 2013. Kant on Emotions and Williams Criticism. In: Veritas, vol. 58, no. 1, pp. 131-150.

MA, X. J. - LIN, C. - ZHEN, W. 2008. Cancer Care in China: A General Overview. In: Biomedical Imaging and Intervention Journal, vol. 4, n. 3, pp. 2-9.

MARX, K. - ENGELS, F. 1950. Selected Works. Foreign Language Publishing House, Moscow.

MEAD, G. H. 1967. Mind, Self and Society from the Standpoint of Social Behaviourist. Chicago University Press, Chicago.

MUSHINI, V. 2016. Level of Cancer Awareness among College Students in from South India. In: Annals of Oncology, vol. 27, n. suppl. 9, pp. 235-242.

OLSON, R. 2015. Toward a Sociology of Caregiving: Time and Feel. Ashgate Publishing Limited, Furnham.

PERRY, D. C. - GLOVER, T.D. 2011. Living with Cancer? Come As You Are. In: Qualitative Inquiry, vol. 17, n. 5, pp. 395-403.

Profile Poznań for AXA Life and Social Foundation "Ludzie dla Ludzi". 2014. Choroba nowotworowa - doświadczenia pacjentów. Poznań.

RENAUlT, E. 2008. Souffrance Sociales, Philosophie, Psychologie et Politique, Editions la Découverte. Paris.

SCHEFF, T. J. Toward Integration in the Social Psychology of Emotions. In: Annual Review of Sociology, vol. 9, pp. 333-354.

SILBERMANN, M. - ARNAOUT, M. - DAHER, S. - NESTOROS, B. PITSILLIDES, H. - CHARALAMBOUS, M. - GOULTEKIN, R. - FAHMI, M. K.KHLEIF, A.D. - MANASRAH, N. - OBERMAN, A. 2012. Palliative Cancer Care in Middle Eastern Countries: Accomplishments and Challenges. In: Annals of Oncology, vol. 23, n. suppl. 3, pp. 15-28.

SIMMEL, G. 1950. The Metropolis and Mental Life. In: The Sociology of Georg Simmel. New York Free Press, New York 1950, pp. 409-424

SIMPSON, C. 2014. The Practice of Palliative Care from the Perspectives of Patients and Carers. In: BMJ Supportive \& Palliative Care, vol. 4, n. 3, pp. 291-298.

THOITS P. A., The Sociology of Emotions [in:] Annual Review of Sociology, Vol. 15 (1989), pp. 317-342

TWIGG. J. - ATKIN K., Carers perceived: Policy and Practice in Informal Care, Open University Press, Maidenhead 1994.

TZANELLI, R. 2007. Gift. In: G. Ritzer (ed.): Blackwell Encyclopedia of Sociology. Oxford: Blackwell Publishing.

Union For International Cancer Control. 2013. World Cancer Day 2013 - Global Press Release, Geneva.

VERTIGANS, S. - SUTTON, P. 2002. Globalization Theory and Islamic Praxis. In: Global Society, vol. 16, n. 1, pp. 31-46.

WEI, R. - WEIL, S. - WILKINSON, I. - YOO, G. J. - AVIV, C. - LEVINE, E. G. EWING, C. - AU, A. 2011. Civilization and Culture. In: Globality Studies Journal, n. 24, pp. 1-9.

Additional Internet Resources:

http://www.academia.edu/2521946/Social_Suffering_as_an_Approach_to_Human_U

nderstanding

https://www.cancer.org/cancer/cancer-basics/what-is-cancer.html http://www.cancerresearchuk.org/about-cancer/utilities/glossary/?letter=C http://www.second-opinions.co.uk/cancer.html\# https://www.tasa.org.au/thematic-groups/groups/sociology-of-emotions-and-affect/.

Words: 8205

Characters: 55198 (30,66 standard pages) 
Prof. dr hab. Leon Szot, PhD.

Faculty of Social Sciences

Pontifical University of John Paul II in Krakow

Kanonicza 25

31-002 Kraków

Poland

leon_szot@poczta.onet.pl

Prof. PhDr. Kamil Kardis, PhD.

Greek Catholic Theological Faculty

University of Presov in Presov

Ul. Biskupa Gojdica 2

08001 Presov

Slovak Republic

kamil.kardis@unipo.sk

Prof. PaedDr. ThDr. Gabriel Pala, PhD.

Greek Catholic Theological Faculty

University of Presov in Presov

Ul. Biskupa Gojdica 2

08001 Presov

Slovak Republic

gabriel.pala@unipo.sk

Ulbossyn Aimbetova, PhD.

Kazakh national academy of choreography

9 Uly dala avenue, 010000 Nur-sultan

Kazahstan

aimbetovau@gmail.com 